Государственный академический университет гуманитарных наук Мароновский переулок, д. 26, Москва, 119049, Россия imhocorg@gmail.com

Аннотация. В статье представлены результаты сравнительного анализа взаимодействия ключевых субъектов, принимающих участие в решении местных проблем, в регионах, отличающихся социокультурными уровнями модернизации. На примере двенадцати регионов РФ проверена гипотеза о том, что уровень цивилизационного развития оказывает значимое влияние на отношения субъектов в процессе управления развитием регионов. В качестве ключевого параметра анализа рассмотрена субъектность участников, как деятельностная характеристика, проявляющаяся во взаимодействии их друг с другом. Поскольку взаимодействие субъектов оценивается с точки зрения влияния на будущее регионов, то предметом анализа стала не субъектность, как свойство субъекта, а субъектность, как качественная характеристика цели (т.е. как субъекты оказывают влияние на решение региональных проблем). Определены и интерпретированы характеристики субъектности взаимодействия решения региональных проблем, позволяющие проводить измерения. В основу отнесения регионов к определенному типу социокультурного развития положена адаптированная под руководством Н. И. Лапина методика Китайской академии наук по определению уровней цивилизационного различия в процессе модернизации. Эмпирическим материалом выступили результаты исследований «Гражданская экспертиза проблемы реформирования властно-управленческой вертикали в контексте процессов социокультурной модернизации регионов: от мониторинга состояний до прогнозного проектирования» и «Академический проект: управляемость процессов социального группообразования в регионах с разным уровнем социокультурной модернизации и поддержка населением стратегии развития РФ до 2024 года», проведенного ЦСУ и СТ ИС ФНИСЦ РАН. Использованы данные полевого опроса, онлайн-опроса экспертов и контент-анализа средств массовой информации. Выявлено, что взаимодействие ключевых субъектов по решению региональных проблем имеют неоднородные отличия, которые нивелируются при получении средних результатов для каждого уровня социокультурной модернизации. Несмотря на то, что регионы движутся с разными цивилизационными скоростями, эта особенность не является значимой при формировании отношений между субъектами. Для определения факторов, влияющих на субъектность решения региональных проблем, предлагается провести качественное исследование взаимодействия субъектов по реализации в регионах национальных проектов.

Ключевые слова: социология управления; субъектность цели; субъектность будущего; социокультурные особенности; развитие регионов 
Информация для цитирования: Демьяненко В.И. Субъектность решения проблем в регионах с разным уровнем социокультурной модернизации // Научный результат. Социология и управление. 2021. Т. 7, № 4. С. 75-95. DOI: 10.18413/2408-9338-2021-7-4-0-5.

Research article

\title{
Vasily I. Demyanenko $\quad$ Subjectivity of problem solving in regions with different levels of socio-cultural modernization
}

State Academic University for the Humanities

26, Maronovskiy Lane, Moscow, 119049, Russia

imhocorg@gmail.com

\begin{abstract}
The article presents the results of a comparative analysis of the interaction of key actors involved in solving local problems in regions with different levels of socio-cultural modernization. On the example of twelve regions of the Russian Federation the hypothesis that the level of civilizational development has a significant impact on the relations of subjects in the management of regional development was tested. The subjectivity of the participants as an activity characteristic that manifests itself in their interaction with each other was studied as a key parameter of the analysis. Since the interaction of subjects is evaluated in terms of influencing the future of regions, the subject of the analysis was not subjectivity as a property of the subject, but subjectivity as a qualitative characteristic of the goal (i.e. how subjects influence the solution of regional problems). The characteristics of the subjectivity of the interaction of regional problem solving were defined and interpreted, allowing the measurements to be carried out. The basis of assigning regions to a particular type of socio-cultural development was based on the methodology of the Chinese Academy of Sciences, adapted under the guidance of N. I. Lapin to determine the levels of civilizational difference in the process of modernization. The empirical material included the results of the studies "Civil Expertise of the Problem of Reforming of Power and Administration Vertical in the Context of Socio-Cultural Modernization of Regions: from Monitoring of States to Projection Design" and "The Academic Project: Manageability of Social Group Formation Processes in Regions with Different Levels of Socio-Cultural Modernization and Population Support of the Development Strategy of RF until 2024", conducted by CSU and STS RAS FNISC. The data of the field survey, online survey of experts and content-analysis of mass media were used. It was revealed that the interaction of key actors in solving regional problems have heterogeneous differences, which are levelled when obtaining average results for each level of socio-cultural modernization. Despite the fact that the regions move at different civilizational speeds, this feature is not significant in the formation of relations between subjects. To determine the factors influencing the subjectivity of solving regional problems, it is proposed to conduct a qualitative study of the interaction between the subjects on the implementation of national projects in the regions.
\end{abstract}

Keywords: sociology of management; subjectivity of the goal; subjectivity of the future; socio-cultural characteristics; regional development

Information for citation: Demyanenko, V. I. (2021), "Subjectivity of problem solving in regions with different levels of socio-cultural modernization", Research Result. Sociology and management, 7(4), 75-95. DOI: 10.18413/2408-9338-2021-7-4-0-5. 
Введение (Introduction). Проводимые в Российской Федерации в 2021 году структурные изменения в аппарате правительства по перестройке работы, связанной с экспертизой и планированием правительственных решений, установление правовых оснований для координации государственных и региональных органов власти, значительные бюджетные ассигнования на финансирование проекта по организации цифрового государственного управления свидетельствуют о том, насколько важна организация процессов управления для адекватной работы с современными вызовами и угрозами. При этом надо отметить, что комплексность решаемых проблем, возрастающая динамика взаимодействий, глобальность процессов создают трудности для применения классических подходов управления, характеризующихся механистическими взглядами, жестким планированием, поиском обоснованных решений без учета особенностей того, кто их будет исполнять. Желаемое будущее при решении сложных проблем, к которым относятся социально-экономические и социокультурные, не является запланированной константой, оно может быть вероятностным, изменяться по мере приближения к ожидаемому (в связи с открывшимися обстоятельствами или изменением расклада сил между субъектами). Поэтому ученые и практики ставят вопрос не только о том, как управлять, но и кто управляет. Исследуется способность индивидуальных и коллективных субъектов управления быть проактивными, обучаться в меняющихся обстоятельствах, преодолевать трудности вопреки прогнозам. Для анализа этих особенностей используется понятие «субъектность», описывающее способность субъекта быть ответственным за свое развитие с учетом социальной действительности. Необходимость его введения в управлении связана с пластом проблем, когда субъект не обладает достаточным социальным капиталом или не имеет внутренних оснований для того, чтобы проявлять активность (такое состояния называют бессубъект- ным). В. А. Лепский пишет, что на сегодняшний день в российском государстве об этом свидетельствуют неумение субъектов взаимодействовать, их неспособность самоопределиться, адекватно оценивать ситуацию, неготовность реализовывать прорывные идеи (Лепский, 2019).

Традиционно субъектность рассматривалась с точки зрения самого субъекта насколько он способен самостоятельно делать выбор, ставить цель, исходя из своих интересов и отвечать за свое развитие. А. И. Пригожин, анализируя процессы управления, предложил изменить ракурс и посмотреть на феномен субъектности с точки зрения цели. Ведь в управлении нередко так случается, что есть руководитель, в обязанности которого входит ответственность за результат, но не имеющий достаточных полномочий, ресурсов или причин действовать. Для подобных ситуаций и был предложен термин «субъектность цели», как характеристика качества цели. Она «есть выделение субъектной (авторской, творческой, волевой) ее составляющей» (Пригожин, 2010: 114). Но в таком взгляде опускается важная социальная особенность - на интересующее будущее оказывают влияние разные субъекты.

В проблемной ситуации, в управлении достижением цели можно выделить объективные факторы, подчиняющиеся естественным закономерностям, детерминированные обстоятельствами, и факторы субъективные, являющиеся следствием волюнтаристских усилий людей, групп, движений и т.П. При этом последние определяются субъектностью не одного субъекта. Так, например, Т. Парсонс при описании волюнтаристского социального действия, направленного на достижение цели, указывал, что актор оказывается во взаимоотношениях с другими субъектами (Парсонс, 2000). Т.е., рассматривая цель, нам необходимо учитывать всех субъектов, оказывающих на него влияние. При этом у такого будущего могут быть как сторонники, так и противники, что можно 
описать в рамках концепции П. Блау, предложившего разделять отношения, в основе которых лежит конкуренция или интеграция (Ритцер, 2002). В этом случае под «субъектностью цели» необходимо понимать взаимодействие субъектностей участников относительно решаемой проблемы. И тогда объектом исследования и управления выступает не личность или группа людей, а особенности их взаимодействия. Например, А. А. Мерзляков предлагает рассматривать субъектность, как важную характеристику диагностирования управления «в ситуациях оценки характера социальных отношений между властно-управленческой вертикалью и населением» (Россия: реформирование, 2017: 129). По мнению В. Е. Лепского, бессубъектность, как болезнь, хотя и в разной степени, но поразила и наше государство, и общественные сообщества, и социальные институты. Выходом из этого состояния он видит адекватное взаимодействие субъектов. При этом предлагается изучать его не только в рамках системного подхода, а с позиции полисубъектной среды, где разные акторы действуют в определенной культурной атмосфере (Лепский, 2019).

Решение социально-экономических и социокультурных проблем происходит с помощью социальных механизмов и способов воздействия на людей и социальные группы. Изучение таких управленческих отношений и взаимодействий относится к проблемному полю социологии управления. Одним из важных параметров, характеризующих поведение индивидуальных и коллективных субъектов, принимающих участие в решении проблем, выступает социокультурный контекст. Существующие традиции, ритуалы, формальные и неформальные нормы задают форматы взаимодействий и роли сторон. В научной литературе используется понятие национальной модели управления, раскрывающей устоявшиеся в обществе культурные нормы процессов управления (Демьяненко, 2014). Одной из знаковых идей в этом направлении является описанное М. Вебером влияние на практику взаимодействия между людьми протестантской этики, обусловившей производственные отношения западной модели управления. В качестве противоположной модели принято описывать восточную, в частности, японскую. В том и другом случаях различие в культуре управления обосновывается национальными традициями (Речкин, 2009). А. П. Прохоров, исследуя российскую историю управления государством, пришел к выводу, что национальная модель не является статичной, а зависит от ситуаций (например, в стабильные периоды управление связанно с количественным ростом, а во времена перемен происходит аварийномобилизационное освоение нового). Модель управления стремится соответствовать уровню социально-экономического развития, типичному образу жизни и другим особенностям ситуации (Прохоров, 2017).

В этом контексте важно понимать, как социокультурные особенности влияют на субъектные взаимодействия, можно ли выделить устоявшиеся правила проявления активности или отказа от нее, какие субъекты предпочитают вступать в конкуренцию, а какие и когда - объединяют усилия. А. В. Тихонов формулирует этот вопрос как зависимость особенностей управления от цивилизационного тренда развития (Россия: реформирование, 2017). Особую важность данный вопрос приобретает в связи с тем, что географическое пространство России, исторические и культурные особенности ее частей ведут к различию в уровне процессов модернизации. показывает социокультурные портреты регионов страны в Атласе модернизации России. Основываясь на российской и международной статистике и социологических опросах, Н. И. Лапин выделяет четыре взаимозависимые компоненты цивилизационного развития: технологическую, социально-экономическую, социокультурную, регулятивную. Важно отметить, что, согласно составителям Атласа, именно со- 
средоточенность на социокультурных проблемах модернизации придала исследователям многослойного модернизационного пространства России целеустремленности и оказалась наиболее продуктивной (Атлас модернизации России, 2016).

С точки зрения социологии управления, интерес в первую очередь представляют социальный и регулятивный аспекты развития. В центре социокультурной характеристики находятся содержание и условия жизни / работы людей, действующие социальные институты и их влияние на другие компоненты. Институционально-регулятивный аспект, по мнению А. В. Тихонова, относится к качеству управления, и его можно рассматривать одновременно как следствие и причину происходящих изменений. При этом особенности социокультурной модернизации должны влиять и на форматы субъектности региона (Россия: реформирование, 2017).

В связи с тем, что регионы страны движутся с различными «цивилизационными скоростями» и их можно рассматривать в качестве субъектов со своей историей и культурными особенностями, мы предполагаем, что существует связь между уровнем развития региона и способом организации субъектного взаимодействия в решении региональных проблем. Проверка этой гипотезы является целью данного исследования. При ее подтверждении можно говорить о важности учета региональных социокультурных особенностей; в противном случае необходимо искать иные факторы, оказывающие влияние на качество управления при решении местных проблем.

Методология и методы (Methodology and methods). Объектом данного исследования выступили взаимодействия субъектов по решению проблем в разных регионах Российской Федерации. В качестве субъектов рассматриваются группы людей, идентифицирующих себя с определенной общностью и принимающих участие в решении проблем региона.
Предметом исследования такого процесса взаимодействия стало соотношение их субъектностей в процессе развития регионов. Это позволяет, с одной стороны, учесть влияние всех заинтересованных сторон, а с другой - исключить из анализа тех субъектов, которые не оказывают должного воздействия.

Понятие «субъектность» - деятельностная характеристика, описывающая способность субъекта самостоятельно принимать решения и исполнять их. Спецификой социологического взгляда на этот феномен является соотнесение себя с другими участниками (Мерзляков, 2018). Для нас представляет интерес субъектность не с точки зрения интересов кого-то из субъектов, а с точки зрения будущего конкретного региона, того, как решаются его проблемы. Т.е. необходимо проанализировать, как субъектность каждого субъекта влияет на развитие региона.

Экспликация субъектного взаимодействия относительно общего будущего в социологических дисциплинах отсутствует, поэтому мы определим самостоятельно параметры и индикаторы, позволяющие провести измерения. В основание положим ключевую особенность феномена субъектности - активность, выраженную в формировании будущего. Именно на нее обращал внимание А. Н. Леонтьев (которому приписывают авторство данного термина) и другие психологи в рамках деятельностного подхода (Леонтьев, 2004). В социологии важность учета активности как для личности, так и для макросубъектов подчёркивается в деятельно-активистской парадигме. В. А. Ядов, характеризуя субъектность, обращает внимание на активность субъекта в результате осознания своего интереса, отличного от других (Ядов, 1995, 2001). Поэтому важно учесть то, как интересы субъекта соотносятся с решением проблем региона. Для стабильных ситуаций и конкретных целей можно было бы рассмотреть направление 
активности - на достижение должного или, наоборот, создающего трудности в его достижении. Но при решении сложных проблем, не имеющих однозначного решения, при котором видение должного будущего претерпевает изменения со временем, удобнее воспользоваться идеей П. Блау. Он выделяет взаимодействия, построенные на конкуренции, приводящей к социальной дифференциации, и на интеграции для достижения общих целей (Ритцер, 2002). Т.е. нам важно выяснить, совпадают ли в какой-то степени интересы субъектов или нет, определив стремление действовать сообща. При этом важно учитывать, что декларации целей и обоснование результатов могут не соответствовать истинным причинам поведения субъектов. Поэтому в качестве показателей и индикаторов были выбраны те характеристики, которые отображают функциональные особенности субъектов в процессе решения проблем.

С учетом вышесказанного, задачами исследования являются:

- определение ключевых субъектов, участвующих в решении проблем регионов;

- дифференциация субъектов в их взаимодействии друг с другом;

- определение заинтересованности субъектов в будущем регионов (направленность активности);

- сравнение полученных результатов между регионами, различающимися уровнями социокультурной модернизации.

С 2015 по 2021 года командой под руководством А. В. Тихонова проводилась аналитическая работа по вопросам реформирования вертикали управленческой власти и управляемости процессов группообразования с учетом социокультурных уровней регионов (Богданов 2018; Демьяненко, 2020; Мерзляков, 2018а; Мерзляков, 2018b; Россия: реформирование, 2017). Накопленные за это время данные позволяют провести необходимый анализ.
С учетом ограниченности финансирования исследования и методических средств, в круг анализа попали 12 субъектов федерации из разных Федеральных округов, экономических и географических районов России. Уровни социокультурной модернизации каждого из них определялись с учетом адаптированной для российской действительности группой Н. И. Лапина методики Китайской академии наук; идентификация с каждым уровнем осуществлялась на основе структурных идентификаторов, учитывающих двухсотлетнюю историю (Атлас модернизации России, 2016). Были составлены информационные карты региональных различий, куда входили общие показатели развития региона (такие как основные фонды, инвестиции в капитал, дотационный статус и пр.) и количественные (отражающие культурноисторическое наследие). Получилось четыре группы:

- высокий уровень развития - Московская, Свердловская и Нижегородская области;

- средний - Амурская, Вологодская и Белгородская области;

- ниже среднего - Башкортостан, Республика Саха, Омская область;

- низкий - Калмыкия, Смоленская область, Дагестан.

В качестве субъекта, к сфере ответственности которого отнесено решение региональных проблем (обеспечение безопасности, создание социальной инфраструктуры, экономическое развитие), рассматриваются региональные органы власти и управления (далее Регион). Вторым важным субъектом, заинтересованным в будущем региона, выступают его жители (далее Население). Речь идет о людях, которые идентифицируют себя с социальной общностью, ограниченной регионом проживания (среди опрошенных самоидентифицируются так от 78,2\% до $89,9 \%$ ). Среди них есть те, кто не готов участвовать в развитии и те, кто, наоборот, стремятся к такому участию (люди с активной гражданской позицией, 
интеллектуальная элита, местное самоуправления, социальные объединения, независящие от властей). Третьим субъектом, оказывающим на регион значительное влияние, выступает центральный аппарат страны - правительство, отраслевые министерства, Совет Федерации, Государственная дума (далее Центр).

Анализ деятельности субъектов, облеченных властью, показывает, что в качестве эмпирических индикаторов направленности их интересов удобно рассматривать: цели использования ресурсов, приоритет нужд населения, соответствие действий обещаниям. Оценка направленности Населения учитывала: участие людей в решении общественных проблем; вовлеченность в действия общественных организаций; роль самоуправления. Для изучения особенностей взаимодействия Региона и Центра использовались такие показатели, как: суверенитет региональных властей, способность отчитываться, навыки построения конструктивных отношений. Отношения между Регионом и Населением были рассмотрены через изучение: привлечения населения к решению проблем; учета пожеланий жителей региона; электоральную активность; объединяющую роль местных средств массовой информации. Взаимодействие Центра и Населения оценивалось на основе индикаторов: электоральной активности; отношения к поведению федеральной администрации по отношению к региональным властям; признания необходимости изменения центрального аппарата.

В статье использованы данные, полученные посредством разных инструментов сбора первичной социологической информации с 2015 по 2020 гг. Полевой опрос представил 5452 полевых документа. Квотная выборка осуществлена пропорционально группам населения согласно данным переписи населения. Распределения оценок параметров близки к нормальному распределению, что позволило рассчитывать стандартное отклонение. Онлайн-опрос экспертов собрал массив из 591 анкет с ответами на открытые вопросы. Его валидность достигается благодаря компетентности участников опроса, подтверждаемой профессиональными характеристиками в области управления. Контент-анализ средств массовой информации охватил выборку из 1669 статей, опубликованных в 21 региональном издании. Благодаря этому мы можем проанализировать изучаемые вопросы с учетом отношений между указанными выше субъектами.

Научные результаты и дискуссия (Research Results and Discussion). Полученные в результате исследования данные позволили сравнить субъектность взаимодействия в процессе решения проблем регионов, отличающихся социокультурными уровнями модернизации. Для описания такой субъектности вначале следует показать, каким образом строятся взаимодействия по решению проблем между каждой парой субъектов, а затем проанализировать направленность их деятельности. Для большей наглядности при сравнении будут использоваться диаграммы.

Проведенные исследования (в частности, анализ оппозиционных и лояльных власти печатных изданий) свидетельствуют о том, что отношения между Регионами можно исключить из анализа, т.к. региональные органы власти воспринимают себя фактически в отрыве от других (незначительное вовлечение в общие проекты, отсутствие стремления посягать на суверенитет другого региона).

Для описания взаимодействий Региона и Центра накоплен значительный эмпирический материал. Начнем рассмотрение с оценок экспертами суверенитета региональных органов управления (рис. 1). Средние показатели по всем уровням развития регионов попали в интервал «скорее уважают, но очень ощутимы ограничения со стороны центра». При этом соответствующие регионы, отнесенные к нижнему и высокому уровням, показывают меньшую зависимость. В целом, схожесть показателей эксперты объясняют политикой федеральных органов, выстраиванием вертикали власти. 


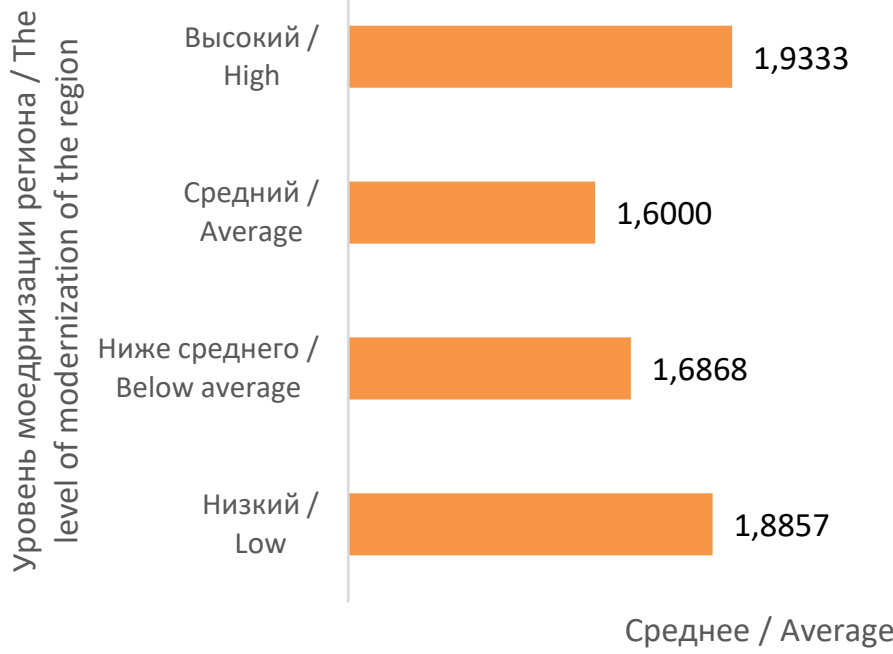

Рис. 1. Экспертные оценки уважения суверенитета региональных властей центральным аппаратом (балльная оценка: 1 - ограничивает во всем; 2 - ощутимы ограничения; 3 - достаточная свобода действий)

Fig. 1. Expert assessments of respect for the sovereignty of regional authorities by the central apparatus (point score: 1 - restricts everything; 2 - restrictions are palpable;

3 - sufficient freedom of action)

В целом по мнению 81,45\% экспертов, Регионы опираются на поддержку президента, правительство, полпреда в округе, органы представительной власти.
Можно сделать вывод, что во взаимоотношениях между Регионом и Центром достигнуто согласие относительно распределения прав и обязанностей.

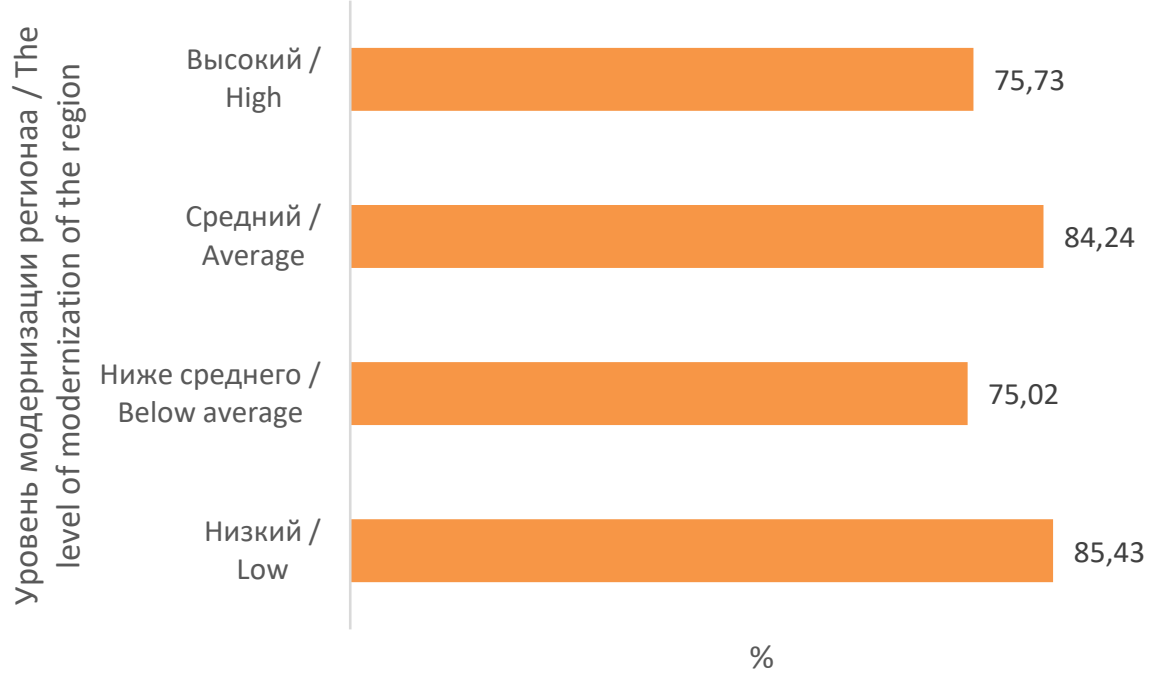

Рис. 2. Экспертные оценки стремления аппарата руководства региона опираться на поддержку сверху

Fig. 2. Expert assessments of the desire of the regional government apparatus to rely on support from above 
Способности местных властей строить конструктивные отношения с правительством страны, отраслевыми министерствами, Советом Федерации, Государственной думой представлены в интегральных оценках (рис. 3). Согласно полученным данным, здесь не наблюдается зависимости от регионов нижнего уровня модернизации к высокому уровню - спе- циалисты оценивают «почти хорошо» эту способность для уровней высокого и ниже среднего, в то время как у нижнего и среднего он чуть не дотягивает до этой оценки.

Относительно умения Региона отчитываться перед Центром на рисунках 4 и 5 приведены оценки населения регионов и экспертов в области управления.

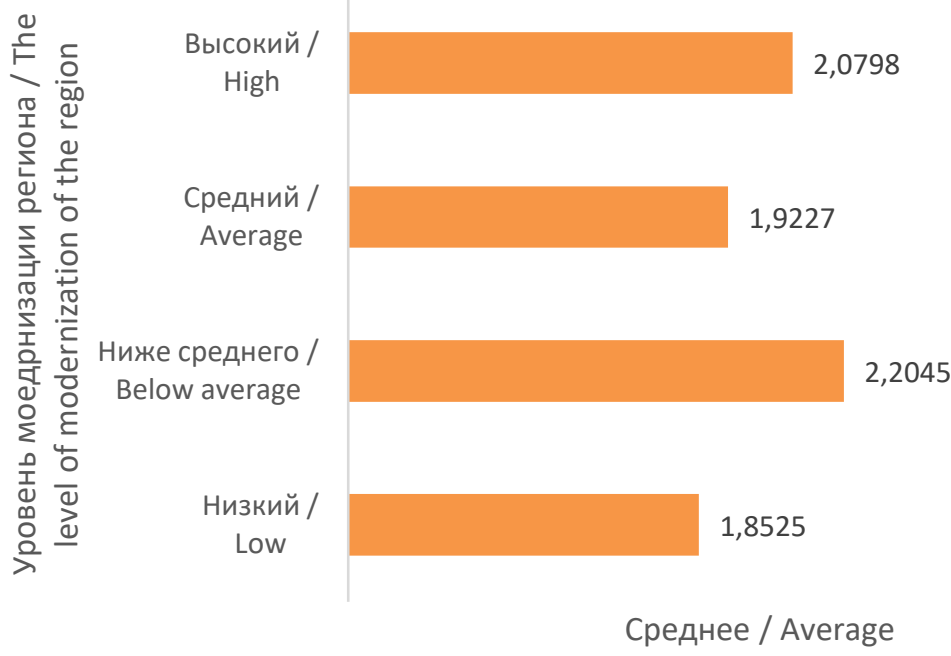

Рис. 3. Экспертные оценки способности системы управления регионов строить конструктивные отношения с центральным аппаратом страны (балльная оценка: 1 - плохо; 2 - удовлетворительно; 3 - хорошо)

Fig. 3. Expert assessments of the ability of the regional management system to build constructive relations with the central apparatus of the country (point score: 1 - bad; 2 - satisfactory; 3 -good)
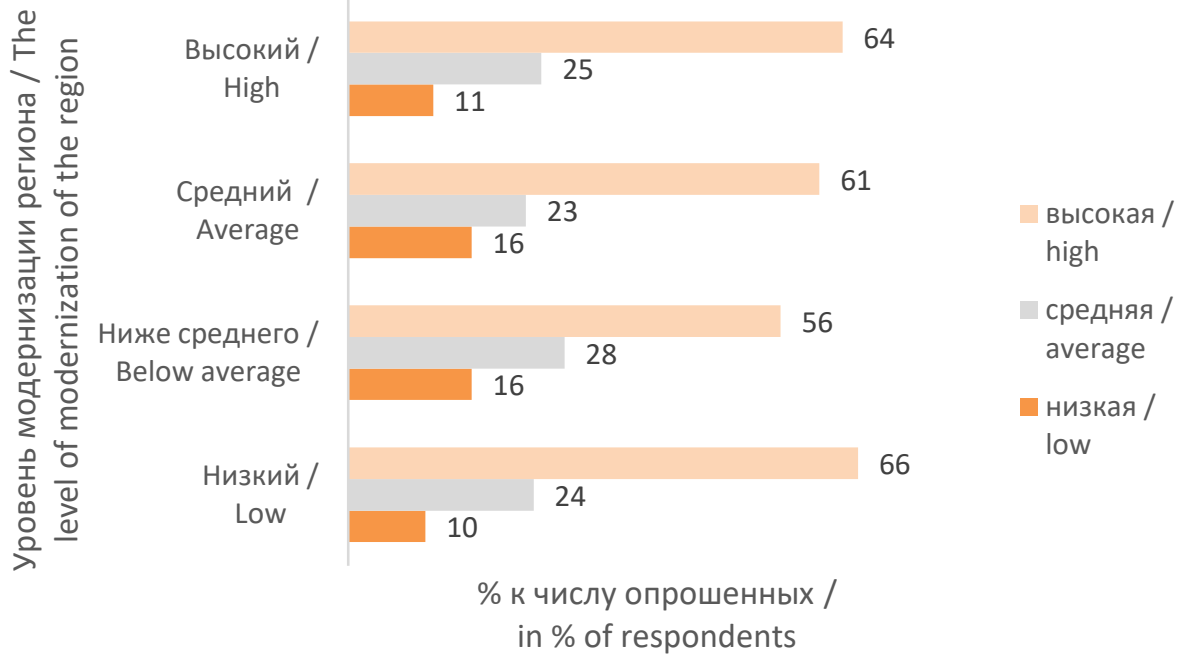

Рис. 4. Степень обеспокоенности опрошенных тем, что система управления ориентируется не на дело, а на отчетность перед вышестоящей инстанцией

Fig. 4. The degree of concern of the respondents that the management system is focused not on business, but on reporting to a higher authority 
Независимо от социокультурного уровня модернизации региона, население выказывает значительную обеспокоенность (в целом только 21\% опрошенных проявили низкую степень беспокойства) тем, что региональная система управления ориентируется не столько на достижение результатов, сколько на отчетность перед Центром. И эксперты согласны в этом, т.к. уверены в хороших навыках Регионов предоставлять отчетность.

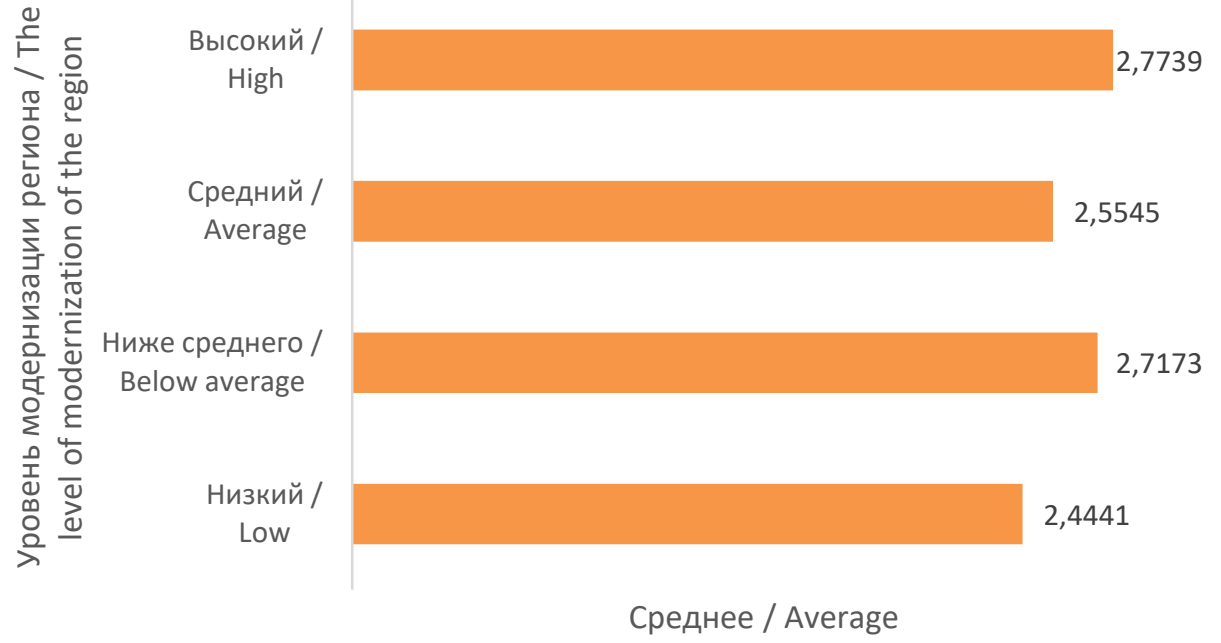

Рис. 5. Экспертные оценки умения системы управления регионов хорошо отчитываться перед вышестоящей организацией (балльная оценка: 1 - плохо; 2 - удовлетворительно;

$$
3 \text { - хорошо) }
$$

Fig. 5. Expert assessments of the ability of the regional management system to report well to a higher organization (point score: 1 -bad; 2 - satisfactory; 3 -good)

Представленные данные индикаторов, характеризующих взаимодействие Регионов и Центра, не имеют значимых отличий, указывающих на важные особенности, между регионами, отличающимися социокультурными уровнями модернизации. Посмотрим, как обстоит с этим дело между Регионом и Населением. Начнем с того, насколько обеспокоены жители регионов игнорированием их инициативы.

В среднем лишь $15 \%$ опрошенных отмечают низкую обеспокоенность тем, что властями игнорируется инициатива снизу, а около половины респондентов выражают высокую озабоченность (рисунок 10). Только $11,48 \%$ экспертов отмечают стремление Региона привлекать к совместной деятельности разные группы населения (интегральный показатель учитывает работников промышленности, научно- технической и гуманитарной интеллигенции, городское и сельское население). В регионах с низким уровнем социокультурного развития данный показатель опускается до 8,15\% (рисунок 6).

Несмотря на распространенность в стране онлайн общения и наличие интернет-сайтов органов власти, эксперты оценивают возможность использования их для обсуждения проблем региона в целом средне (немного выделяются на этом фоне регионы со средним социокультурным уровнем развития) (рис. 7). В открытых вопросах специалисты отмечали, что нередко для населения закрыт доступ к общественно значимой информации, а возможности общения не создаются. При этом заметна активность людей в соцсетях и независимых форумах. 


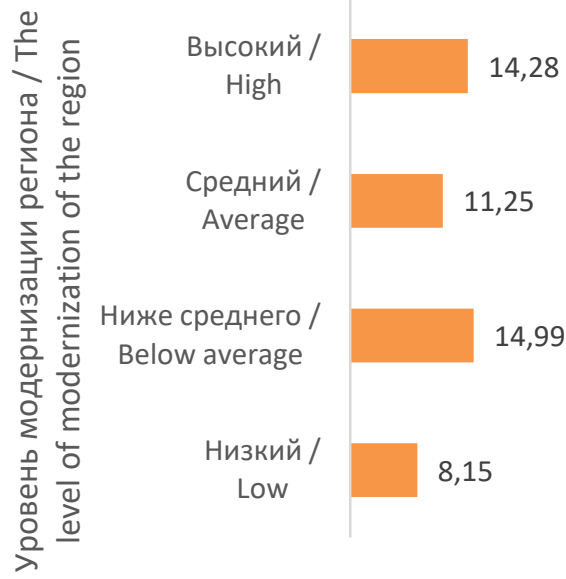

в \% к числу опрошенных /

in $\%$ of respondents

Рис. 6. Экспертные оценки стремления аппарата руководства региона привлекать к управлению различные группы населения

Fig. 6. Expert assessments of the desire of the regional administration to involve various groups of the population in management

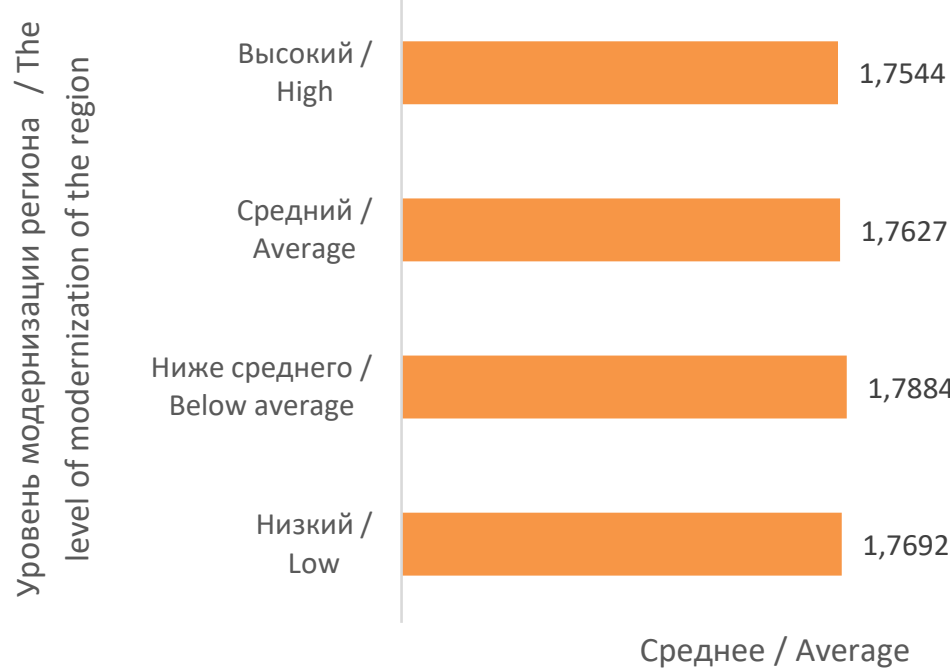

Рис. 7. Экспертные оценки доступности обсуждения социально значимых проблем региона на сайтах местных властей (балльная оценка: 1 - низкая; 2 - средняя; 3 - высокая)

Fig. 7. Expert assessments of the availability of discussion of socially significant problems of the region on the websites of local authorities (point score: 1 - low; 2 -medium; 3 - high)

Вероятно, онлайн возможности, предоставляемые региональными порталами, влияют на количество обращений в органы власти с помощью сети. От 13,5\% до $23,5 \%$ жителей активно пользуются онлайн возможностями для общения с местными органами управления (рис. 8).
Мы видим заметные отличия, но это не последовательное увеличение от низкого уровня модернизации к более высокому. При этом важно отметить, что более половины опрошенных уже имеет опыт такого общения. 


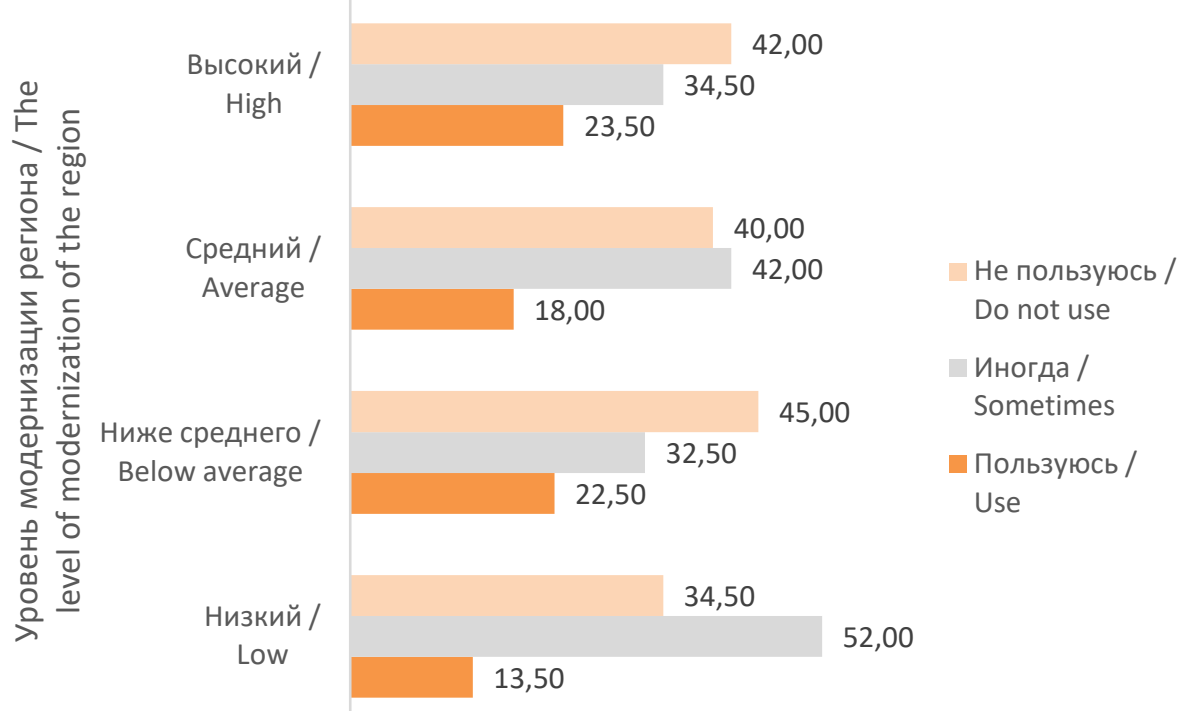

\% к числу опрошенных / in \% of respondents

Рис. 8. Проявление активности жителей региона путем онлайн-обращений Fig. 8. Demonstrating the activity of the residents of the region through online appeals

Интегральный показатель учета Регионом пожеланий Населения составлен с учетом экспертных оценок органов власти в части решения общественных проблем, знания запросов людей, учета мнений и критических высказываний населения об их деятельности (рис. 9).

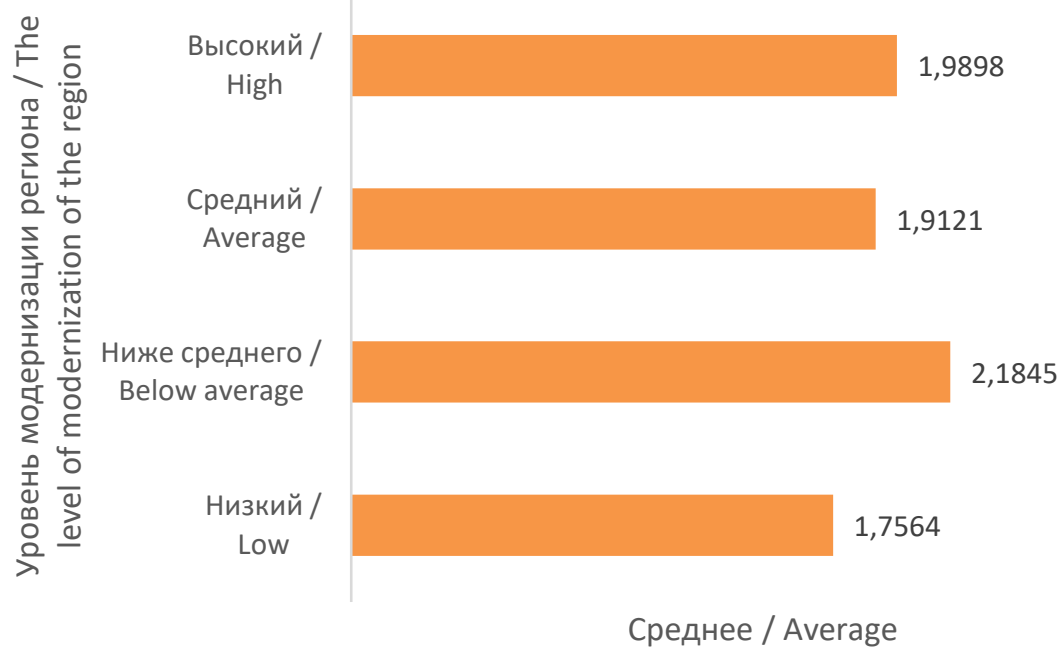

Рис. 9. Экспертные оценки работникам местных органов власти за активность в решении проблем с учетом пожеланий населения (балльная оценка: 1 - плохо; 2 - удовлетворительно; 3 - хорошо)

Fig. 9. Expert assessments to employees of local authorities for their activity in solving problems, taking into account the wishes of the population (point score: 1 - bad; 2 - satisfactory; 3 - good) 
Используя существующие возможности общения с представителями органов власти в регионах, различающихся социокультурными уровнями модернизации, наблюдаем схожие низкие результаты (рис. 10). В целом люди предпочитают самостоятельно справляться с возникающими трудностями. Средства массовой информации выступают в качестве поля для обсуждения властями и населением проблем развития регионов. Сегодня, с переходом печатных и др. изданий в интернетпространство, роль СМИ как модератора общения возрастает. Поэтому для оценки использования такого переговорного пол были проанализированы статьи регио- нальных газет. Процент аналитических статей составляет от $28,4 \%$ до $40,2 \%$, что ниже среднего для регионов всех анализируемых уровней. Электоральная активность - способ проявления субъектности, доступный всем жителям региона. Несмотря на это, участие в местных выборах не свидетельствует о высокой активности населения; только в регионах низкого уровня социокультурного развития этот показатель выше среднего (55,15\%).

Для сравнения особенностей взаимодействия Региона и Населения используем лепестковую диаграмму, представив в ней часть рассмотренных выше показатели в процентах от числа опрошенных.

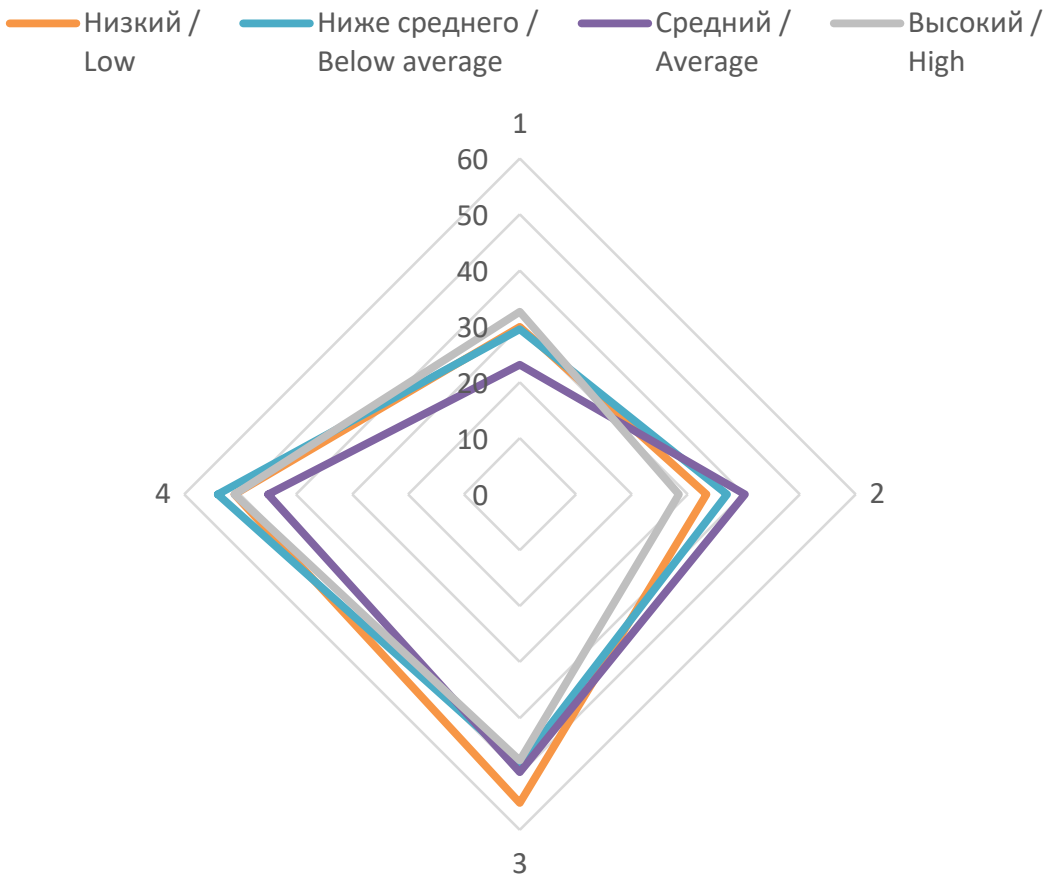

Рис. 10. Взаимодействие Региона и Населения в регионах, отличающихся социокультурными уровнями модернизации (в \%)

Fig. 10. Interaction between the Region and the Population in regions with different levels of socio-cultural modernization (in \%)

1 - граждане обращаются в органы власти / citizens apply to the authorities

2 - аналитические статьи в региональных СМИ / analytical articles in regional media

3 - электоральная активность на местных выборах / electoral activity in local elections

4 - озабоченность населения игнорированием инициативы снизу / public concern about ignoring the initiative from below 
Несмотря на различия в данных, на диаграмме заметно сходство образующихся фигур между регионами, различающимися социокультурными уровнями модернизации.

Проанализируем отношения Населения и Центра. Упоминавшийся ранее опрос экспертов свидетельствовал о том, что Центр «скорее уважает», но ощутимо ограничивает право Регионов самостоятельно решать проблемы их развития (см. рис. 1). Опрос жителей регионов всех уровней показывает невысокую степень одобрения предоставления Центром прав Регионам самостоятельно распоряжаться своими ресурсами. Такую позицию можно объяснить направленностью интересов региональных органов управления (см. ниже).

Опрос региональных экспертов свидетельствует об их уверенности в том, что власти государства справятся с вызовами и угрозами (рис. 11). Это дает им основания надеяться, что благодаря общим успехам страны и в регионах также произойдут улучшения.

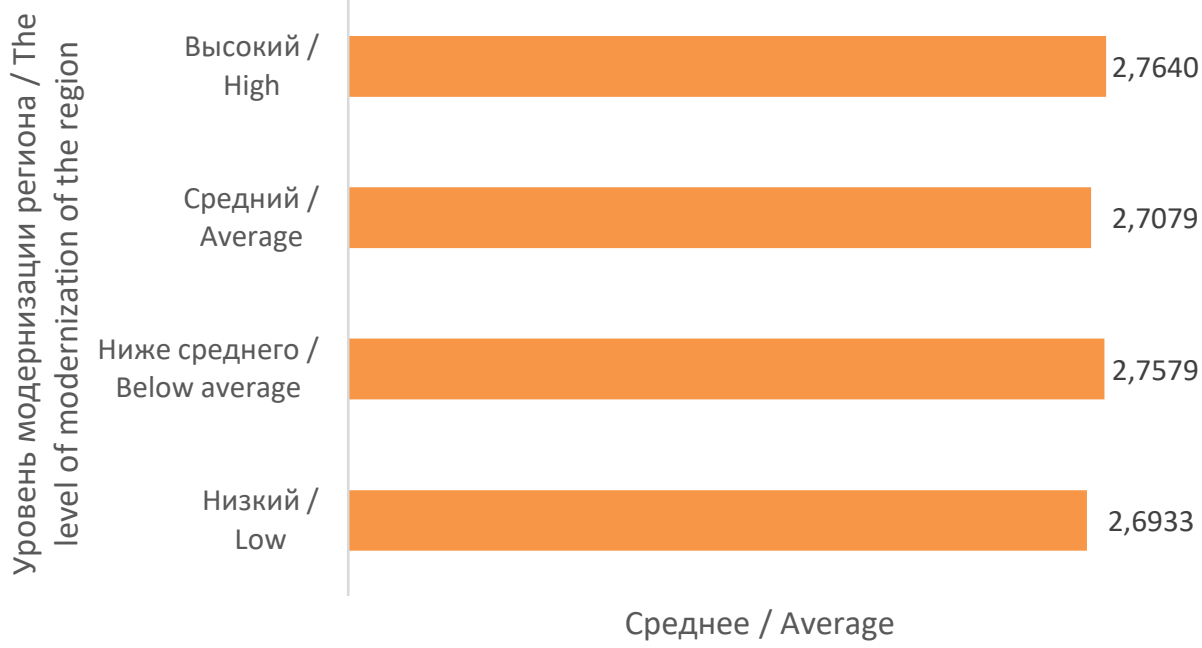

Рис. 11. Экспертные оценки способности властей справиться с вызовами перед страной ( 1 - ухудшатся; 2 - не изменятся; 3 - улучшатся)

Fig. 11. Expert assessments of the authorities' ability to cope with challenges to the country ( 1 - will worsen; 2 - will not change; 3 - will improve)

Опрос показывает, что в целом $38 \%$ населения необходимость изменять работу центрального аппарата оценивают высоко, a $36 \%$ - средне. И эти показатели схожи в регионах различного уровня социокультурной модернизации.

Электоральная активность при голосовании на выборах в Президенты и Государственную думу (рис. 12) значительно выше, чем в региональные органы (см. рис. 10). Это согласуется с надеждой людей на то, что успехи страны в целом положи- тельно скажутся на их регионе (см. рис. 11) и значительным одобрением населением низкого суверенитета региональных властей. На рисунке 12 наглядно показаны ряды параметров, характеризующих отношения между Населением и Центром. Здесь тоже можно видеть отличия между регионами, различающимися социокультурными уровнями модернизации, но они не оказывают влияния на графические фигуры, обладающие значимым сходством. 


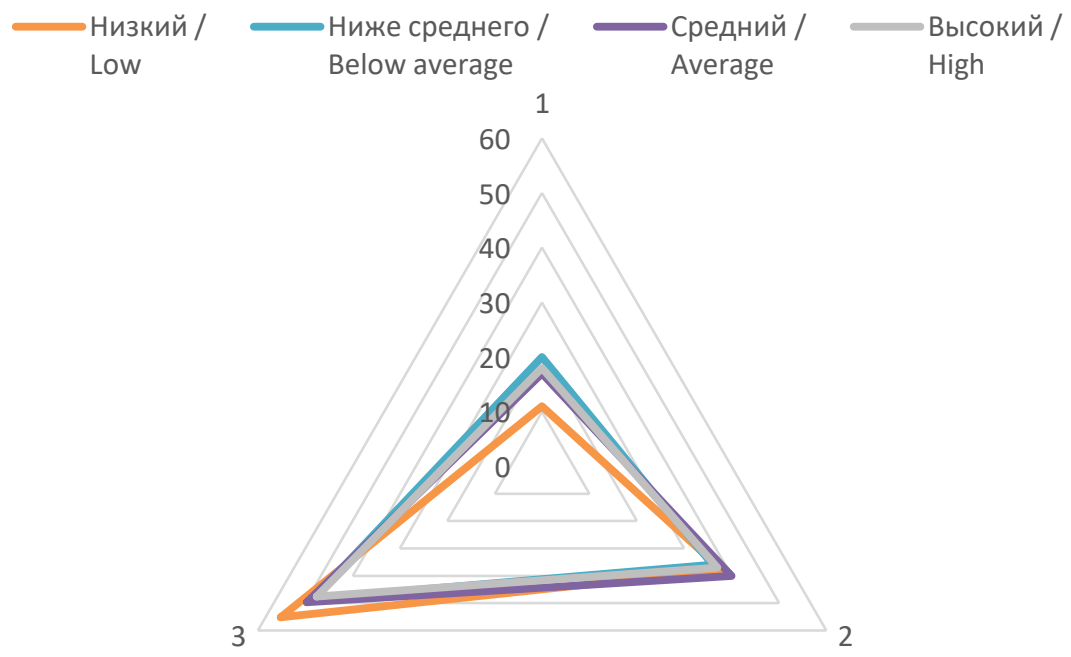

Рис. 12. Взаимодействие Центра и Населения в регионах, отличающихся социокультурными уровнями модернизации (в \% от числа опрошенных)

Fig. 12. Interaction between the Center and the Population in regions with different levels of socio-cultural modernization (in \% of respondents)

1 - высокая степень одобрения предоставления Центром прав Регионам использовать свои ресурсы / a high degree of approval of the granting by the Center of the rights to Regions to use their resources

2 - высокая оценка необходимость изменения работы Центра / high assessment of the need to change the work of the Center

3 - электоральная активность на федеральных выборах / electoral activity in federal elections

После того как рассмотрены отношения между всеми субъектами развития регионов, проанализируем направленность интересов по отношению к необходимости решать местные проблемы. Начнем с Центра. Опрошенные жители регионов и эксперты оценивают федеральный уровень управления значительно выше регионального. Больше половины респондентов высоко оценивают работу центральной исполнительной власти, несколько ниже федеральную законодательную и судебную по сравнению с местной. При этом эксперты в открытых вопросах отмечают, что Центр при принятии решений не стремится учитывать мнение регионов, но, с другой стороны, они же считают, что поведение центральных органов в целом позитивно влияет на региональную ситуации.
Можно сделать вывод о том, что, по мнению опрошенных, федеральные органы власти имеют свое понимание путей развития регионов и стараются выстроить вертикаль власти, требуя от других субъектов присоединиться к достижению поставленных целей.

Движущие причины и направленность интересов Региона логично начать с оценки степени обеспокоенности жителей регионов тем, что местные власти используют ресурсы в личных целях (см. рис. 14). Согласно получены данным, для всех уровней развития характерна значительная обеспокоенность этим показателем (в целом 59\% опрошенных ее оценивают высоко и $27 \%$ средне).

Значительную обеспокоенность у населения вызывает то, что представители 
власти превращаются в клику (органы местных властей согласуют свои социальные, экономические, политические интересы для удовлетворения корыстных целей с помощью государственных институтов). Еще больше опрошенные жители регионов разных уровней цивилизационного развития обеспокоены ориентацией действий руководства региона в первую очередь на сохранение власти - в целом высокую степень обеспокоенности проявляют $63 \%$ (см. рис. 14).

Опрос экспертов свидетельствует о том, что стремление Регионов сохранять приоритет запросов и нужд местных жителей находится на среднем уровне, и это качественно не зависит от социокультурного уровня модернизации (рис. 13).

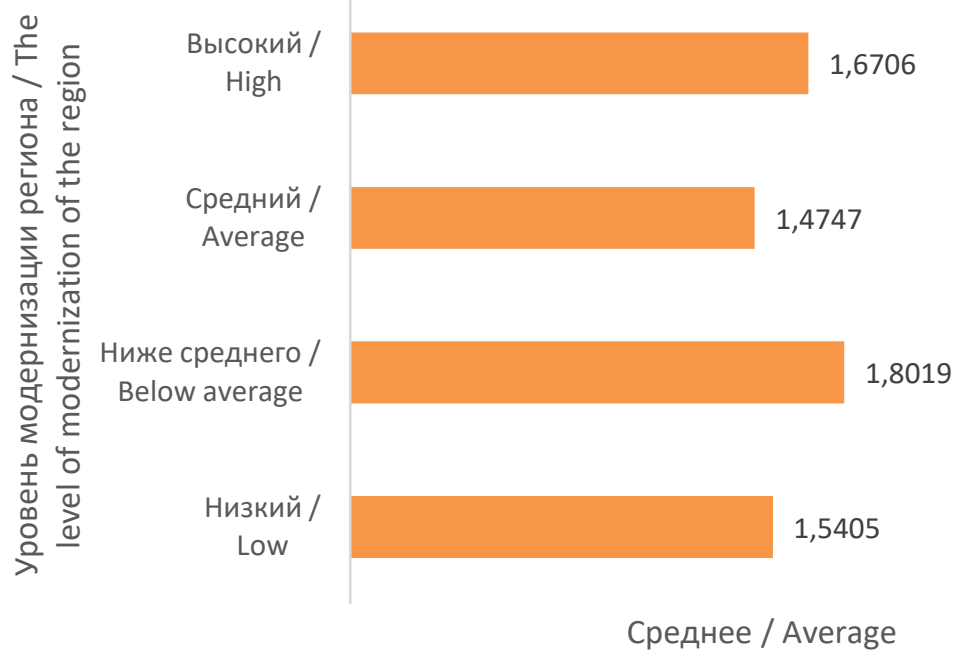

Рис. 13. Экспертные оценки региональных властей в любых ситуациях сохранять приоритет нужд и запросов простых людей

(в средних баллах: 1 - плохо, 2 - удовлетворительно, 3 - хорошо).

Fig. 13. Expert assessments of regional authorities in all situations to maintain the priority of the needs and demands of ordinary people (with average scores: 1 - bad, 2 - satisfactory, 3 -good).

Также в целом 59\% опрошенных обеспокоены несоответствием заявлений руководства регионов о целях и планах даже не результатам, а самим действиям, осуществляемым Регионом (рис. 14). Наглядно разница направленности интересов между регионами разного уровня представлена на лепестковой диаграмме с помощью четырех параметров, выражен- ных в процентах. Нетрудно заметить, что графики имеют одинаковую форму и немногим различаются в части выраженности значений. В целом они свидетельствуют о том, что опрошенные жители существенно обеспокоены тем, что субъектность Регионов направлена на удовлетворение частных интересов властных групп. 


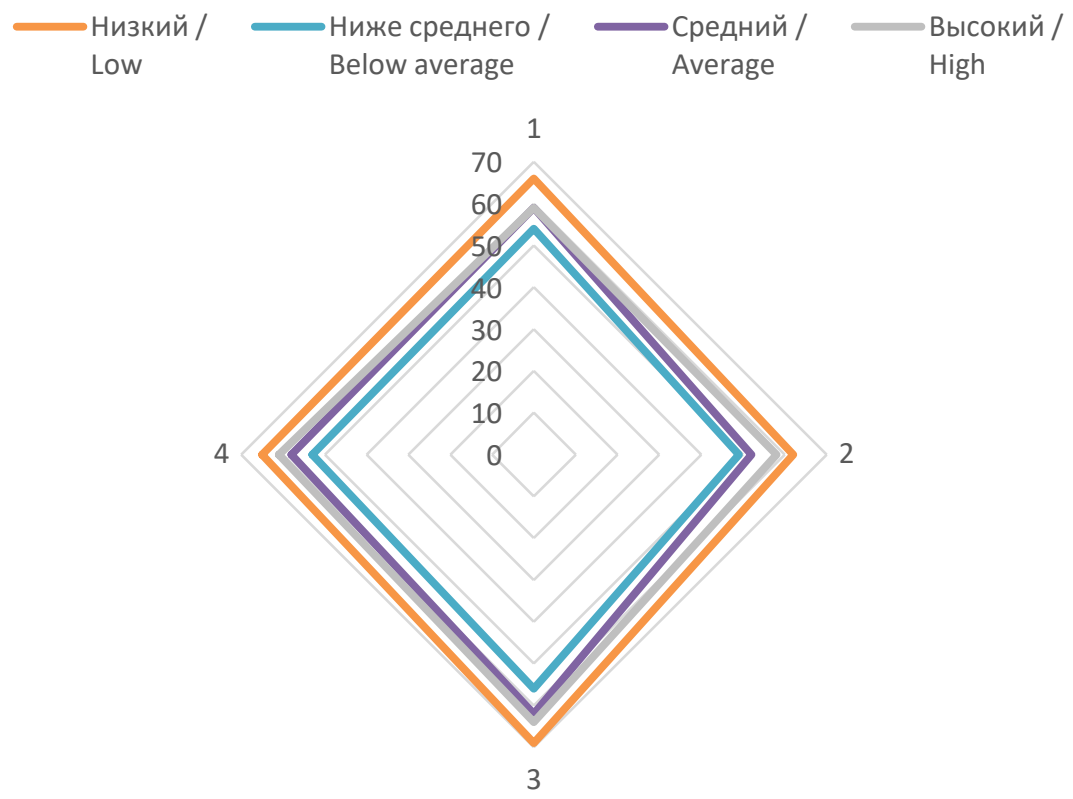

Рис. 14. Особенности направленности активности региональных органов власти и управления (в \% к числу опрошенных)

Fig. 14. Features of the orientation of the activity of regional authorities and administration Степени обеспокоенности тем, что: / Levels of concern that:

1 - руководство использует ресурсы организации в личных целях / management uses the organization's resources for personal gain

2 - что руководящий состав превращается в междусобойчик / the management team turns into a get-together

3 - руководство ориентируется на сохранение власти / leadership is focused on maintaining power

4 - действия руководства не соответствуют словам и обещаниям / the actions of the management do not correspond to the words and promises

Оценивая направленность субъектности Населения, в первую очередь обратим внимание на уровень его активности. Согласно мнению экспертов, участие граждан в решении местных проблем оценивается на границе между плохо и удовлетворительно (рис. 15). Заметно ниже обстоят дела в регионах с низким уровнем социокультурной модернизации - 0,8671.

Рядовые жители, давая оценку своему участию в решении общественных проблем, активности, откровенности и компетентности в выражении мнений, в целом лишь в $34,1 \%$ случаев считают их высокими (см. рис. 16), что подтверждает мнение экспертов (рис. 15).

Опрос показывает, что вне зависимости от социокультурного уровня модернизации менее четверти населения вступают в общественные движения или участвуют в организуемых ими мероприятиях. Согласно данным опроса местных жителей регионов, они не склонны возлагать надежды на органы местного самоуправления. В целом только 23\% из них проявили высокую степень одобрения повышению роли самоуправления. На рисунке представлены три параметpa, результирующих данные опроса местных жителей. Лепестковая диаграмма наглядно показывает, что для регионов с разным уровнем социокультурной модернизации форма рисунков почти совпадает. Видно, что для всех характерна активность ниже $40 \%$, а для регионов с низким уровнем цивилизационного развития процент участия в решении общественных проблем региона и одобрение повышения роли самоуправления даже заметно меньше. 


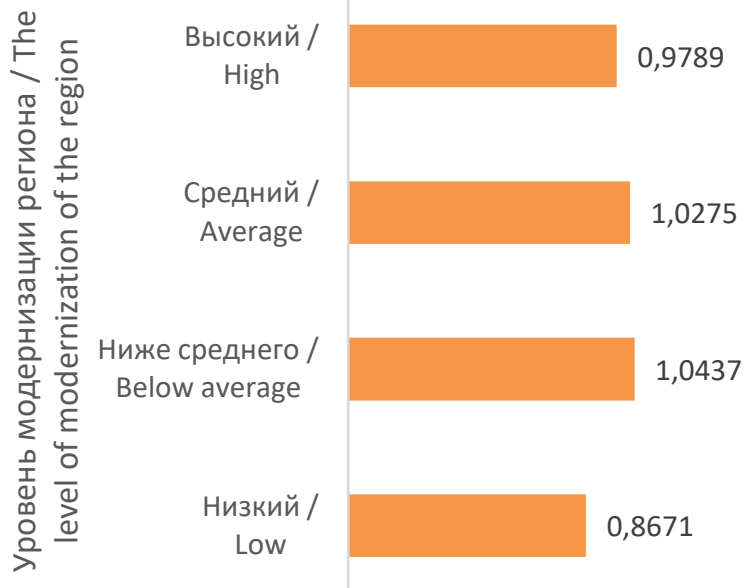

Среднее / Average

Рис. 15. Экспертные оценки населению за участие в решении проблем региона (в средних баллах: 1 - плохо, 2 - удовлетворительно, 3 - хорошо).

Fig. 15. Expert assessments of the population for their participation in solving the problems of the region (with average scores: 1 - poor, 2 - satisfactory, 3 -good).

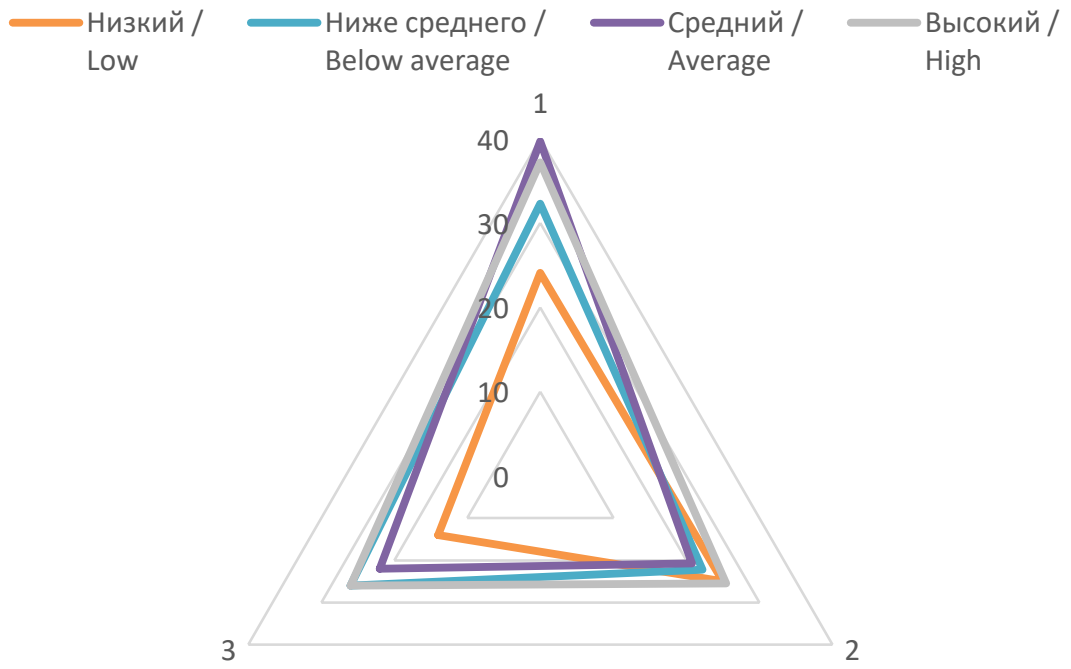

Рис. 16. Особенности активности населения регионов (в \% к числу опрошенных)

Fig. 16. Features of the activity of the population of the regions (in $\%$ of respondents)

1 - высокая оценка населением своего участия в решении общественных проблем региона / high assessment by the population of their participation in solving social problems of the region 2 - процент опрошенных, участвующих в общественной деятельности / percentage of respondents participating in social activities

3 - высокая степень одобрения опрошенными повышения роли самоуправления / high degree of approval by the respondents of the increased role of self-government 
Заключение (Conclusions). В данной работе субъектность трактуется, как способность индивидуального или коллективного субъекта в конкретной ситуации быть ответственным за свое развитие с учетом социальной действительности - субъект преобразует ее, а та, в свою очередь, оказывает влияние на становление субъекта. В контексте решения проблем регионального развития важно проанализировать влияние социокультурных особенностей регионов на проявление их субъектности.

В управлении субъектность представляет интерес не только как свойство субъекта, но и как качественная характеристика должного будущего. Ее называют субъектностью цели, и она показывает, существует ли у цели субъект, заинтересованный, способный и несущий ответственность за ее достижение. Но поскольку на желаемое будущее оказывают влияние разные субъекты (как сторонники, так и противники достижения цели), нами предлагается оценивать субъектности всех взаимодействующих в этом процессе участников. Понятие «субъектность», являясь деятельностной характеристикой, раскрывает, насколько активен субъект и каковы его движущие причины. Это позволяет рассмотреть основные особенности процесса взаимодействия региональных субъектов по решению проблем. Для этих целей определены параметры и индикаторы, позволяющие оценить и описать особенности отношений в процессе решения региональных проблем.

Проанализированные данные не являются фактами управления. Это субъективные картины (представления, понимания, восприятия) жителей регионов, наблюдающих за реальными событиями по решению проблем. Тем не менее, для управления важна полученная возможность сравнивать мнение обычных граждан, экспертов-профессионалов в управлении, журналистов. На основании этой информации мы не можем ставить окончательный «диагноз», но сделанные выводы должны привлечь внимание, натолкнуть на серьезные размышления.

Несмотря на то, что в каждом отдельном регионе по-разному проявляется активность субъектов, для данного исследования более важное значение имеет их сравнение с учетом уровня социокультурного развития региона. В этом случае мы наблюдаем, как нелинейные связи приобретают большое сходство.

Субъектность взаимодействия центрального аппарата управления, региональных властей и жителей региона относительно будущего регионов рассмотрена сквозь призму двух основных параметров: направленности интересов субъектов и особенностей их взаимодействия.

Анализ направленности интересов субъектов относительно решения проблем регионов показал, что центральные органы занимают активную позицию и имеют свое понимание целей развития регионов. Региональные власти представляются хорошо организованным субъектом, деятельность которого вызывает у большинства граждан и экспертов серьезное беспокойство тем, что государственные институты используются в частных целях. Население в целом не проявляет большого интереса к участию в решении общественных проблем и самостоятельно справляется с возникающими проблемами. Такие интересы основных субъектов регионального управления свидетельствуют о расхождении в понимании ими того, какие проблемы и как решать, а их субъектности можно назвать разнонаправленными. Само же взаимодействие между субъектами имеет схожие черты. Федеральная власть заметно ограничивает суверенитет региональных органов управления, настаивая на развитии регионов в соответствии со своим видением. Последние, в свою очередь, научились выстраивать отношения с Центром - находят поддерж- 
ку сверху, но ориентируются скорее на отчетность, а не реальное дело. При этом они не выказывают заинтересованности в инициативе и участии разных категорий местных жителей. Население же регионов c большей надеждой смотрит на деятельность центральных органов, считая, что общее улучшение в стране позитивно скажется и на их регионе.

Полученные результаты указывают на то, что социокультурный уровень модернизации региона не относится к ключевым факторам, определяющим особенности взаимодействия субъектов при решении местных проблем. Мы считаем, что для повышения интегрированности усилий включенных в развитие регионов субъектов необходимо провести качественное исследование особенностей субъектности взаимодействия по достижению конкретных целей, стоящих перед регионами (например, национальных проектов). Это позволит выявить и конкретизировать тех субъектов, которые оказывают значимое влияние, а также факторы, определяющие характеристики их взаимодействия. Как следствие, мы сможем лучше понимать механизмы взаимодействий при решении региональных проблем (постановке целей, организации деятельности, анализе результатов).

\section{Список литературы}

Атлас модернизации России и ее регионов: социоэкономические и социокультурные тенденции и проблемы: коллективный научный труд / сост. и отв. ред. чл.-корр. РАН Н. И. Лапин. М.: Весь Мир, 2016. 360 с.

Богданов В. С. Информатизация регионального управления: проблемы и перспективы // Вестник Института социологии. 2018. № 25. С. 27-47.

Демьяненко В. И. Работа над российской моделью управления «экстремальное стратегическое проектное управление» // Российская модель управления: анализ и рекомендации к применению: Материалы всероссийской научно-практической конференции. ХантыМансийск, 2014. С. 90-95.
Демьяненко В. И. Субъектность региональных органов власти в социальном теле проблемы реформирования системы управления в процессе социокультурной модернизации регионов // Социология и общество: традиции и инновации в социальном развитии регионов: Сборник докладов VI Всероссийского социологического конгресса. М., 2020. C. 2485-2496.

Леонтьев А. Н. Деятельность. Сознание. Личность. М.: Смысл, 2004. 352 с.

Лепский В. Е. Методологический и философский анализ развития проблематики управления. М.: Когито-Центр, 2019. 340 с.

Мерзляков А. А. Проблема субъектности в социологии управления // Социологическая наука и социальная практика. 2018. № 4. C. $95-104$.

Мерзляков А. А. Субъектность регионов и ее значение для реформирования // Вестник Института социологии. 2018. № 25. С. 48-65.

Парсонс Т. О. О структуре социального действия. М.: Академический Проект, 2002. $880 \mathrm{c.}$.

Пригожин А. И. Качество целей // Общественные науки и современность. 2010. № 1. C. 114-126.

Прохоров А. П. Русская модель управления. М.: Студии Артемия Лебедева, 2017. $496 \mathrm{c}$.

Речкин Д. Н. Российская модель управления: социокультурные факторы формирования и специфика. Волгодонск: ВПО, 2009. $176 \mathrm{c}$.

Ритцер Дж. Современные социологические теории. СПб.: Питер, 2002. 688 с.

Россия: реформирование властноуправленческой вертикали в контексте проблем социокультурной модернизации регионов [монография] / отв. ред. А. В. Тихонов. М.: ФНИСЦ PAH, 2017. $432 \mathrm{c}$.

Ядов В. А. Социальные и социальнопсихологические механизмы формирования социальной идентичности личности мир России // Мир России. Социология. Этнология. 1995. № 3-4. С. 158-181.

Ядов В. А. Социальный ресурс индивидов и групп как их капитал: возможность применения универсальной методологии исследования реального расслоения в российском обществе // Кто и куда стремится вести Россию?...: Акторы макро-, мезо- и микроуровней современного трансформационного процесса. 
Международный симпозиум. М.: Московская высшая школа социальных и экономических наук, 2001. С. 310-319.

\section{References}

Atlas of modernization of Russia and its regions: socio-economic and socio-cultural trends and issues: a collective scientific work (2016), in Lapin, N. I. (ed.), Ves Mir, Moscow, Russia. (In Russian)

Bogdanov, V. S. (2018), "Informatization of regional management: problems and prospects", Vestnik Instituta Sotsiologii, (25), 27-47. (In Russian)

Demyanenko, V. I. (2014), "Work on the Russian management model "extreme strategic project management'", Russian management model: analysis and recommendations for use: Materials of the All-Russian Scientific and Practical Conference, Khanty-Mansiysk, Russia, 90-95. (In Russian)

Demyanenko, V. I. (2020), "Subjectivity of regional authorities in the social body of the problem of reforming the management system in the process of socio-cultural modernization of regions", Conference: VI All-Russian Sociological Congress "Sociology and Society: Traditions and Innovations in the Social Development of Regions, Tyumen, Russia, 1098-1108. (In Russian)

Leont'ev, A. A. (2004), Activity. Consciousness. Personality, Smysl, Moscow, Russia. (In Russian)

Lepsky, V. E. (2019), Methodological and philosophical analysis of the development of management problems, Kogito-Center, Moscow, Russia. (In Russian)

Merzlyakov, A. A. (2018), "The problem of subjectivity in the sociology of management", Sotsiologicheskaya nauka i sotsial'naya praktika, (4), 95-104. (In Russian)

Merzlyakov, A. A. (2018), "Subjectivity of regions and its significance for reforming", Vestnik Instituta sotsiologii, (25), 48-65. (In Russian)

Parsons, T. O. (2002), Structure of social action, Transl. by Chesnokova, V.F. and Belanovskiy, S. A., Akademicheskiy proekt, Moscow, Russia. (In Russian)

Prigozhin, A. I. (2010), "Quality of objectives", Social studies and the present, (1), 114-126. (In Russian)
Prokhorov, A. P. (2017), Russian model of management, Studii Artemiya Lebedeva, Moscow, Russia. (In Russian)

Rechkin, D. N. (2009), Russian model of management: sociocultural factors of formation and specificity, VPO, Volgodonsk, Russia. (In Russian)

Ritzer, G. (2002), Modern sociological theory, Transl. by Boykov, A. and Lisicyna, A., Piter, Saint Petersburg, Russia. (In Russian)

Russia: reforming the power-management vertical in the context of socio-cultural modernization of regions (2017), in Tikhonov, A. V. (ed.), FNISTS RAN publ., Moscow, Russia. (In Russian)

Yadov, V. A. (1995), "Social and sociopsychological mechanisms of the formation of the social identity of the personality of the world of Russia”, Mir Rossii. Sotsiologiya. Etnologiya, (3-4), 158-181. (In Russian)

Yadov, V. A. (2001), "The social resource of individuals and groups as their capital: the possibility of applying a universal methodology for studying real stratification in Russian society", in Who and where is seeking to lead Russia? .... Actors of the macro-, meso- and micro-levels of the modern transformation process. International symposium, Moskovskaya vysshaya shkola sotsial'nyh i ekonomicheskih nauk, Moscow, Russia, 310-319. (In Russian)

Статья поступила в редакиию 29 сентября 2021 2. Поступила после доработки 30 ноября 2021 г. Принята к печати 06 декабря 2021 г.

Received 29 September 2021. Revised 30 November 2021. Accepted 06 December 2021.

Конфликты интересов: у автора нет конфликта интересов для декларации.

Conflicts of Interest: the author has no conflicts of interest to declare.

Демьяненко Василий Иванович, старший преподаватель Государственного академического университета гуманитарных наук, Москва, Россия.

Vasily I. Demyanenko, Senior Lecturer, State Academic University for the Humanities, Moscow, Russia. 